症例

術前診断に細胞診が有用であった黄色肉芽腫性胆囊炎の 1 例 公立香住病院外科

高橋節 角 賢 - 田 村 英 明

西江浩白井博之

黄色肉芽睡性胆要炎は比較的稀な疾患であり，悪性瘇湯との鑑別において難佧するこ とが多いが，術前の鑑別診断に吸引細胞診が有用であった 1 例を経験したので，若干の 文献的考察を加えて報告する。症例は63歳の男性, 主訴は腹痛で, 麻疸性イレウスの状 態で来院した. 画像診断では，胆栾底部に腫瘤状の病变を認め悪性腫瘍を否定できなかっ た。このため吸引細胞診を行い，炎症性細胞のなかに細胞質が明るく泡沫状を呈する大 型の細胞を認めた。これらより黄色肉芽腫性胆资を疑い胆豊摘出術のみを行った，摘 出標本では胆震底部に黄白色の腫瘤を認めた。組織診断にても覀性所見は認められず， 黄色肉芽腫性胆賴炎之診断された。

卖引用語：黄色肉芽腫性胆黄炎, 穿刺吸引細胞診

はじめに

黄色肉芽腫性胆留资 xanthogranulomatous cholecystitis (以下 XGC) は比較的稀な疾患であり， 術前に胆竞癌との鑑別が困難である場合が多いここの ため術式の選択にあたっては難涉することが多い.今 回われわれは術前診断に穿刺吸引細胞診が有用であっ た 1 例を経験したので若干の文献的考察を加えて報告 する。

\section{症例}

患者：63歳，男性.

主訴：上腹部痛.

既往歴: 平成 2 年 6 月にイレゥスにて入院し, 保存 的加療にて軽快し退院となる。糖尿病を指摘されるる コントロールせず.

家族歴：特記すべきことなし。

現病歴: 平成 4 年 7 月 22 日早朝より徐々に上腹部痛 を訴えるようになる、排便があり，痛みは自制内であっ たが，7月23日になってす痛みが軽減しないため，近 医受診し急性腹症として当院紹介され入院となった。

入院時現症：身長 $168 \mathrm{~cm}$, 体重 $46.5 \mathrm{~kg}$, 血王 $136 / 86$ $\mathrm{mmHg}$, 貟血・黄疸は認めす, 頸部リンパ節の腫大も 認めなかった。胸部理学的所見に特記することなし、腹

1992年11月30日受付 1993年 9 月 6 日採用
部では全体に压痛があり，右下腹部に反跳圧痛を認め た。瘇瘤は認めなかったが，腸雑音は減弱していた。

入院時血液生化学梌査所見：CRP が陽性であった

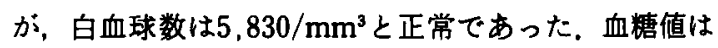
$534 \mathrm{mg} / \mathrm{dl}$ と高値を示した. 肝機能, 腫瘍マーカーには 異常を認めなかった（表1）。

腹部単純 $\mathbf{X}$ 線写真所見: 腹部全体に小腸ガス, niveauを認め麻疸性イレウスと診断した。

腹部超音波検査所見：胆壁の著明な肥厚を認め

\section{表 1 検查所見}

\begin{tabular}{|c|c|c|c|}
\hline \multicolumn{4}{|c|}{ 血液一般検査 } \\
\hline WBC & $5,830 / \mathrm{mm}^{3}$ & & \\
\hline \multicolumn{4}{|c|}{ RBC $468 \times 10^{4} / \mathrm{mm}^{3}$} \\
\hline $\mathrm{Hb}$ & \multicolumn{3}{|l|}{$15.8 \mathrm{~g} / \mathrm{dl}$} \\
\hline Het & \multicolumn{3}{|l|}{$49.7 \%$} \\
\hline Plat & \multicolumn{3}{|l|}{$22 \times 10^{4} / \mathrm{mm}^{3}$} \\
\hline \multicolumn{4}{|c|}{ 生化学検查 } \\
\hline $\mathrm{TP}$ & $7.3 \mathrm{~g} / \mathrm{dl}$ & BUN & $23 \mathrm{mg} / \mathrm{dl}$ \\
\hline GOT & $30 \mathrm{IU} / 1$ & $\mathrm{Cr}$ & $0.8 \mathrm{mg} / \mathrm{dl}$ \\
\hline GPT & $22 \mathrm{IU} / 1$ & T.bil & $1.3 \mathrm{mg} / \mathrm{dl}$ \\
\hline LDH & $116 \mathrm{IU} / 1$ & CRP & $(7+)$ \\
\hline $\mathrm{CPK}$ & $82 \mathrm{IU} / 1$ & CEA & $1.8 \mathrm{ng} / \mathrm{ml}$ \\
\hline ALP & $124 \mathrm{IU} / 1$ & CA $19-9$ & $34 \mathrm{U} / \mathrm{ml}$ \\
\hline$\gamma$-GTP & $70 \mathrm{IU} / 1$ & $\mathrm{HBsAg}$ & $(-)$ \\
\hline AMY & $40 \mathrm{IU} / 1$ & & \\
\hline
\end{tabular}


た. また胆底部に内部エコーが highで不均一な腫瘤 状エコーを認めた。

腹部 CT 検查所見：胆等壁の肥厚と, 内腔の狭小化 を認めた。胆毫底部には讱縁明瞙で内部が不均一なほ ほ円形の腫瘤状病変を認めた，造影 CTでも同様に腫 留状病変を認め。辺縁か造影されていた（図1）。

直接胆震造影所見：超音波ガイドに施行した释皮 経肝胆盖造影では，胆等内空の狭小を認めた（図2）。

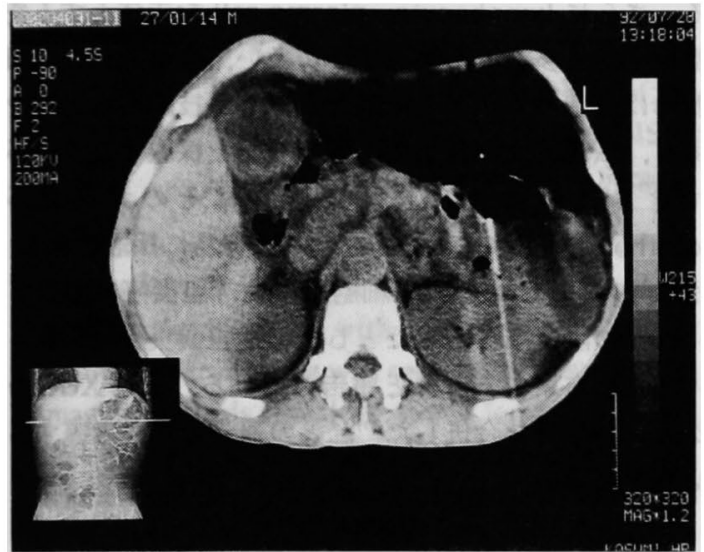

图 1 腹部造影 CT 所見：胆窟底部に円形状腫瘤性の 病変を認める。

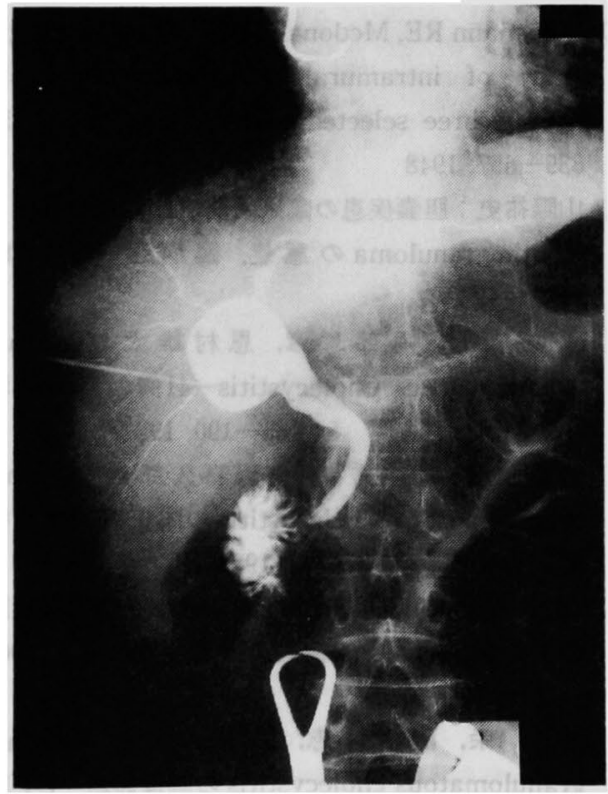

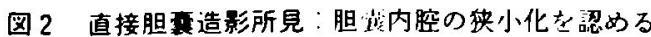
も腫瘤は造影されていない。
胆垔穿刺時の胆汁より，細菌は検出されなかった。

穿刺吸引細胞診所見：胆要底部の腫瘤状病変からの 穿刺吸引細胞診では，出血性背景の中に一部化生様変 化を伴ら細胞がみられた。また変性が強く核の腫大を 伴い，細胞質が明るく泡洙状の細胞が認められた（図 3 ).

以上の所見より XGC む含めた良性の腫瘍性病変を 疑い, 1992年 8 月18日胆路摘出術を行った。

手術所見：胆蔆底部に黄白色の腫瘤を認めた。また 胆垔は，十二指腸，横行結腸に炎症性に強固に瘾着し ていた。

摘出標本所見：切除した胆簧の大きさは8.0×7.4 $\mathrm{cm}$ で胆変壁は1.0〜2.5cm と著明に肥厚していた。胆

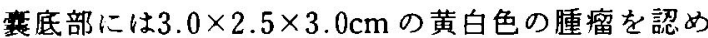
た。胆帻内に結石はなく，病変の周囲組織への浸潤は 認められなかった（図4）.

病理組織学的所見：粘膜はやや過形成であり，獎膜 下層に線維性の結合組織に置換されつつある xanth-

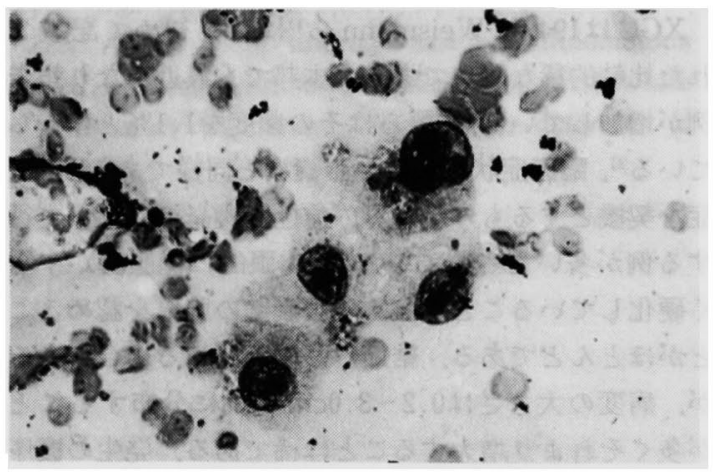

图3穿刺吸引細胞診所見：变性が強く核の腫大を伴 い, 細胞質が明るいxanthoma cell を認める (HE : $\times 200)$

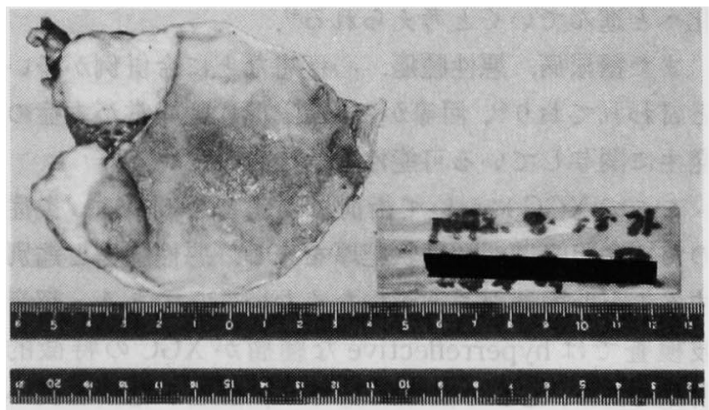

図 4 摘出標本所見：胆就壁の肥厚と，胆程底部には 黄白色の腫瘤を認める $(\mathrm{HE} ： \times 200)$. 


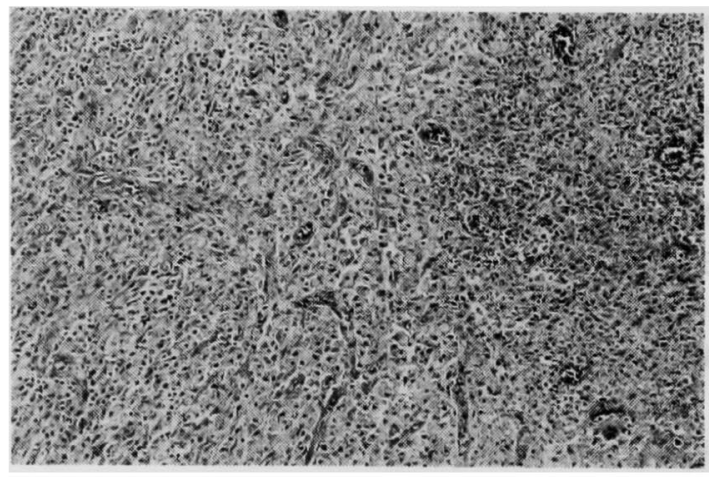

图 5 病理組織学的所見：粘膜はやや過形成で, 漿膜 下層に線維性の結合組織に置換されつつある xanthoma cell の集簇を認め，炎症細胞が散在する。

oma cell の集簇と, 炎症細胞の散在が認められた。こ れらよりXGCと診断され，悪性所見は認められな かった（図５）.

\section{考察}

XGC は1948年 Weismann ら"により初めて記載さ れた比較的稀な疾患であり，本邦です最近になり報告 例が増加している.山際らはその頻度を1.1\%と報告し ている2!. 臨床症状は通常の胆盖炎と同様であり, 胆石 症を契機とするものが多く，急性胆表炎の症状が先行

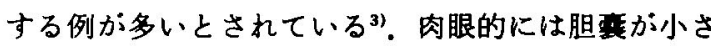
く硬化していることが多く，胆垔壁の肥厚を認めるこ とがほとんどである。結節の形成を認める場合むある が, 病変の大きさは0.2〜3.0 cm の間に分布すること が多くそれより増大することは稀である，発生の機序 はます結石の麻頓などによって, Rokitansky-Aschoff sinus から胆衰壁内に胆汁が侵入しこれを組織球が車 食する. 次いで褐色色素を有する xanthoma cellより なる肉芽腫が形成され, 引き続いて異物性炎症, 線維 化へと進んでいくと考えられる゙.

また糖尿病，悪性腫瘍，心疾患などに合併例が多い と言われており ${ }^{5}$ ，何等かの脂質，糖代謝異常が本症の 発生に関与している可能性す示唆されている.

ここでXGCにおいて術前に問題となるのは，炎症 のために胆壁が腫瘤状肥厚を来し，悪性腫瘍と鑑別 することが困難なことが少なくないことである，超音 波倹查では hyperreflectiveな腫瘤がXGCの特徵的 所見であり，CTの画像所見では胆整癌が粘膜上皮か ら発生するのに対し本症での腫瘤形成は胆壁内であ 门，画像上の腫瘤病変が笳層内に限局して粘膜面に異
常が少ないことを特徵とする報告がみられる6).しか し肝蔵，十二指腸などの周辺缄器に浸潤を伴ったとす る報告むみられ”，術前の画像診断からたけでは悪性 腫瘍を否定しきれない場合が多い，本症例でる腫瘤状 に增殖しており，画像診断からだけでは悪性腫瘍を否 定しきれず穿刺吸引細胞診を行った。

穿刺吸引細胞診においては，明るい泡洙状の細胞質 をむつ豊富な foamy histiocyte（いわゆる xanthoma cell)を証明することがXGCの診断に重要とされてい る.さらに lymphocyte, plasma cell を主体とする资 症性細胞も多数みられることか多い。この穿刺吸引細 胞診は超音波ガイド下に行えるため手技的にも容易で あり，広範囲に腫瘤からの細胞成分を採取することが できる8). 特にXGCによる畽瘤はその大部分が xanthoma cell で占められており，容易に採取できる。 また中澤らりはこの吸引細胞診では，胆衰癌において は80\%の陽性率であったとし，慢性胆变炎と胆萲癌と の鑑別に有用であったと報告している、たた XGCの $20 \%$ に胆霆癌を合併した ${ }^{10)}$ ，との報告もあり考慮する 必要がある。

おわりに

術前診断に，穿刺吸引細胞診が有用であった黄色肉 芽連性胆要炎の 1 例を経験したので，若干の対献的考 察を加え報告した。

\section{文 献}

1) Weismann RE, Mcdonald JR : Cholecystiits ; a study of intramural deposits of lipids in twenty-three selected cases. Arch Pathol 45 : $639-657,1948$

2）山際祐史：胆重疾患の臨床病理 XI. 胆重における Xanthogranuloma の意義. 臨病理 37：381 $-384,1989$

3）涉谷宏行，阿部章彦，恩村雄太：Xanthogranulomatous Cholecystitis-41例の臨床病理 学的検討. 胆と膵 $5: 185-190,1984$

4) 武藤利茂, 山中秀高, 安保喜久郎他: Xantho granulomatous Cholecystitis $の$ 臨床病理学的検 討. 三重医 $33: 37-43,1989$

5）北川 晋, 中川正昭, 山田哲司他：黄色肉芽腫性胆 茠炎の臨床病理学的倹討。日外会誌 91：1001 $-1010,1990$

6）平栄, 清水博志, 大口学他：Xanthogranulomatous cholecystitis $の$ 画像診断-CT 所 見を中心として一。目医放線会誌 $49: 535,1989$

7）岡本攸一郎, 小南達也，山口幸二他：胆露癌と鑑別 
困雜であった黄色肉芽盾性胆资の1例. 胆と膵 $11: 1415-1419,1990$

8) Martha SH, Theodore RM: Diagnosis of xanthogranulomatous cholecystitis by fine needle aspiration biopsy. Acta Cytologica $31: 493$ $-496,1987$
9）中澤三郎，乾 和郎：胆癌の診断-PTCCS K 上万他病変との别。胆と膆 8：1085-1089, 1985

10) Goodman ZD, Ishak KG : Xanthogranulomatous cholecystitis. Am J Surg Pathol $5: 653-659,1981$

\title{
A CASE OF XANTHOGRANULOMATOUS CHOLECYSTITIS IN WHICH ASPIRATION CYTOLOGY WAS USEFUL IN DIFFERENTIAL PREOPERATIVE DIAGNOSIS
}

\author{
Sadamu TAKAHASHI, Kenichi SUMI and Hideaki TAMURA \\ Department of Surgery, Public Kasumi Hospital \\ Hiroshi NISHIE and Hiroyuki SHIRAI \\ First Department of Surgery, Tottori University, Faculty of Medicine
}

Xanthogranulomatous cholecystitis is a relatively rare disease and often presents difficulty in differential diagnosis from malignant tumors. This paper describes a case of this disease in which aspiration cytology was useful in the diagnosis, with a review of the literature.

A 63-year-old man was seen at the hospital because of abdominal pain. The patient presented paralytic ileus. Imaging methods revealed a tumor lesion in the fundus of the gallbladder, and a possible malignancy could not be denied. For this, aspiration cytology was performed. It disclosed large type of cells with cytoplasm presenting as bright and foamy appearance among the inflammatory cells. From these findings xanthogranulomatous cholecystitis was suspected and cholecystectomy was performed. Excised specimen revealed a yellowish white tumor in the Jundus of the gallbladder. Histologically no malignancy was found. The definite diagnosis of xanthogranulomatous cholecystitis was made. 